\title{
PROTECTION OF PUBLIC FINANCE INTERESTS IN TERMS OF PUBLIC FINANCES MANAGEMENT
}

\author{
YULIA GOROSH
}

\begin{abstract}
The article considers the issues related to safeguarding public interest in the process of managing public finances. Based on the analysis of such concepts of financial science as "public finances", "public interest", "levels of public interest development", "interests of different groups" and "public finances functions", the Author has made an attempt to identify and classify current issues in the sphere of safeguarding public interest in the process of managing public finances. According to the Author, the given issues vary in character and nature. The reason for that is that there are several factors that give rise to the given issues. In particular, it's the fact that "public finances" have different functions; there is competition and conflict of interests of different groups of persons in the course of identifying "public interest"; there are common issues that exist in the public sector (bureaucracy, corruption, lack of trust in public institutes, lack of legislation stability); problems in defining "public interest", the sources of "public finances" formation and their allocation (reallocation) at the national, regional and local levels; problems in allocating and delegating authorities among the public authority bodies in terms of "public budgets" development (at the national and local levels).
\end{abstract}

\section{Keywords}

Public interest; public authority functions; public finances functions; levels of public interest development; public income and expenditure

\section{JEL Classification: D63, K34, K40}

1 Candidate of Legal Sciences, Doctoral student for Financial Law, Department of Financial Law and Economics, Faculty of Law, Masaryk University, Czech Republic. Contact email: julia.goros@volny.cz. 


\section{Introduction}

To understand the character of the issues existing in the area of safeguarding "public interest" in the process of state management of "public finances", the Author will make an attempt to analyse what "public finances" and "public interest" are; to characterize them, to identify their nature and goals, to describe the levels of their formation and their functions. An attempt will be made to consider the interconnection with the process of state management and to describe the way "public finances" contribute to the fulfilment of the public authority's functions and serve as an instrument of serving "public interest" Based on this analysis the Author will identify the character and nature of current issues, give them a brief description and classify them.

\section{Public Finances Characteristics, Their Nature and Goals}

In financial law there is a differentiation between public and private finances. P. Mrkývka points it out too that finances should be divided into public and private ones. By "public" he means state and local finances, while private finances are the finances of households and firms (Mrkývka, 2009: 45). M. Bakeš differentiates public and private finances based on the parties and defines "public finances" as the totality of monetary relations connected with formation, allocation and use of the monetary aggregate and its components in the bodies and organizations of the public sector (Bakeš, 2006: 741). P. Mrkývka shares his opinion and writes that "as opposed to public finances, by private finances one should mean the relations connected with the formation, allocation and use of the monetary capital in the private sector that is represented mostly by households and firms" (Mrkývka, 2009: 45).

P.M. Godmet's position is congruent with the given Authors too: "as the allocation of the public product is carried out by the subjects, it is the subject that should be used as the criterion for the classification of financial relations. This allows one to divide finances relatively into public and private ones" (Godmet, 1978: 41). N.A. Scheveleva shares the given viewpoint, too. She points out that "public finances express the part of public monetary relations that is connected with the formation of the monetary funds of public territorial entities that are the financial basis of the state and local government". Based on this, "public finances are a system of monetary relations organized by the state and municipal units, in the course of which public monetary funds are formed and disposed of with the aim of providing for the achievement of the goals and fulfilment of the functions of public authority" (Scheveleva, 2014: 10). 
So when characterizing public finances, we always differentiate them from the private ones. And not only by the parties, but also by their nature and goals.

The first distinctive feature of "public finances", as we have already said, is that it is the kind of economic (monetary, financial) relations that are formed between the state (its bodies, institutes of public authority) on the one hand and other private actors (citizens, households, firms, non-commercial organizations, etc.) on the other. The second feature of "public finances" is that they are relations and operations that appear and take place among the subjects mentioned above in the course of formation, allocation, reallocation and use of public funds. "The system of public finances is formed at the state and local levels" (Mrkývka, 2009: 72). "The system of public monetary funds includes state budgets (federal budget, sub-federal entities budgets)", local budgets, as well as state non-budgetary funds (Scheveleva, 2014: 10). The third characteristic feature of "public finances" is that the reason for their appearance and existence is the necessity to form financial resources for the state to be able to provide public benefits, goods and services in the sphere of health, education, social welfare, public transport, national defence, social security, social allowances, transfers etc., as well as to support the existence of relevant bodies and services that are necessary for achieving the given goals. The fourth peculiarity of "public finances" is that by their nature "public finances" are non-reciprocal, non-equivalent and voluntary. Thus, if we try to summarize everything mentioned above, one could give the following characteristic to "public finances", their nature and the goal of their existence.

1. They are financial relations and transactions between the state (its bodies, institutes of public authority) on the one hand and private actors (citizens, households, firms, non-commercial organizations, etc.) on the other.

2. "Public finances" are monetary relations that appear in the course of formation, allocation, reallocation and use of public funds.

3. They are specific financial relations that have three distinctive features: they are non-reciprocal, non-equivalent and compulsory

4. The reason these financial relations are formed and exist is the need to form the funds (GOAL): for the state to provide private actors with public benefits, goods and services in the sphere of health, education, social security, public transport, national defence and population security, social allowances, grants, transfer payments, etc., as well as for covering the costs of administration of relevant bodies and services necessary to carry out the given tasks. 
5. "Public finances" satisfy the people's needs for public benefits, goods and services at the level of and by the state, region or municipal units, and thus realize the public interest.

6. "Public finances" are an instrument of public policy, the subject of which is public authority and its bodies. With the help of public finances the state realizes the following of its functions:

1. Economic - providing for the economic development of the state, growth of GDP and improving the people's welfare.

2. Social function of providing the so called social benefits, goods and services in the sphere of health, education, social security services, public transport, national defence and public safety, allowances, grants and transfer payments, etc.

\section{Public Finances as Means of Implementation of Public Interest}

As it has been noted in the characteristic of "public finances", they serve the satisfaction of public needs by the state, region and municipality in terms of providing social benefits, goods and services and observing "public interest" in this way.

A lot of Authors mention the fact that "public finances" serve as a means of "public interest" implementation. According to well-known French researcher in the field of financial law, P.M. Godmet, if private finances are oriented mainly at making profit, public finances are "means of implementation of the so called common interest" (Godmet, 1978: 42). M.V. Karaseva thinks that "by public financial activity one should mean the activity of the state, its Authorized bodies, municipal units as well as non-governmental actors that have been charged with the responsibility to perform public tasks in the sphere of finance" (Karaseva, 1998: 152). Speaking about "public interest" one should note that as a rule in scientific literature it is pointed out that "public interest" is an interest of social community recognized by the state and secured by law, the satisfaction of which is the condition and guarantee of its existence (Tikhomirov, 1995: 55). According to A.A. Nechay, public finances are public legal relations connected with the satisfaction of all kinds of public interest and appear in the course of formation, management, allocation (reallocation) and use of public funds and means and control over this process (Nechay, 2005: 15-16). A.A. Nechay mentions that "public interest" exists as some aggregated, average social interest in each of the spheres of social life (Nechai, 2005: 62). Professor Y.A. Tikhomirov points out that the concept of "public interest" is generic and includes more concrete interests (Tikhomirov, 1995: 59-65). The Author of the 
given article believes that formation of "public finances", their allocation and use are aimed at the realization of the following kinds of "public interests":

- Social "public interest" is providing social benefits, goods and services in the sphere of healthcare, education, social security services, public transport, national defence and people's safety, social allowances, grants and transfer payment for private actors by the state (i.e. fulfilment of the social function of the state).

- Economic "public interest" is ensuring stable economic development of the state, growth of GDP and improving the people's welfare (i.e. fulfilment of the economic function of the state).

- Administrative "public interest" is providing for the efficient functioning of the system of public administration and the need for financing the expenditure related to public authorities, local self-government bodies and public corporations activity.

\section{Levels of Public Interest Formation and Interests of Different Groups in Use and Reallocation of Public Finances}

Speaking of "public interest" one should keep it in mind that it can be formed at different levels: state, regional and local. Considering the fact that "public interest" is formed with regard to providing social benefits, goods and services, and their provision must be ensured by the public funds (state, regional or local public budgets), the formation of public budgets takes place at different territorial levels. Depending on the level "public interests" are formed at and at what level the provision of public benefits, goods and services must be financed, the state, regional and local budgets are formed.

It is not only the public funds formation that takes place with the help of public budgets, but it's their reallocation, too. As a result of this reallocation it is possible to transfer the income of a territorial unit that formed it to the public budget of the actor that did not take part in its formation. The efficiency of this kind of reallocation depends on a lot of factors, including: the level of economic development of the region, the quantitative and demographic composition of the population, the level of social requests, climate and location.

Another important issue related to "public interest" and "public finances" is the existence of "interests of different groups" and the competition or sometimes a conflict among them. In the course of public interest formation and reallocation of public resources, the interests of different groups clash. Public finances are a sphere where different, often contradictory and differently directed interests - state, 
group, individual - clash. And in the end the possibility of finding the "resultant" of vectors determines the social, economic and political stability in the state, the possibility of efficient functioning of all public and state institutions.

According to the paradigm that is predominant in financial science today and from the perspective of which the mechanism of formation, allocation and use of "public finances" is considered, as well as the mechanism of "public interest" formation, the implementation of which is the goal of "public finances" it is claimed that there are 4 subjects influence the formation and allocation of "public finances": 1) politicians, 2) the electorate (citizens), 3) public organizations based on common interest principle, 4) bureaucracy (Hamerníková, Maaytová, 2010: 30). Each of the groups tends to protect its own interest, which often leads to competition and conflicts.

\section{Functions of Public Finances as Instrument of Public Policy}

As it has already been noted by the Author of the given article, "public finances" are an instrument of public policy, the subject of which is public authority and its bodies. With the help of public finances the state fulfils the following of its functions:

- Economic function is ensuring stable economic development of the state, GDP growth and improving the welfare of its citizens.

- Social function is providing the so called social benefits, goods and services in the area of healthcare, education, social security, national defence and population safety, allowances, grants and transfer payments, etc.

Taking all of this into account, the Author of the article believes that being an instrument of public policy, "public finances" fulfil some of its independent functions, namely:

- The resources allocation function. The given function includes the activity connected with creation, maintenance and financing public goods and services, as well as public institutes. Regarding the public policy it is decided what public goods, services and bodies and to what extent should be financed from the public funds. The criterion for making decisions here is efficiency.

- The reallocation function is connected with the question of public funds allocation. Regarding the target audiences (social groups) it is decided which groups should be the sources and to which they should be transferred by means of public budget preparations. The criterion here should be fair reallocation. 
- The stabilization function is about the use of "public finances" (income and expenditure) as an instrument that influences the positive dynamics of the economic growth, ensuring stable economic development of the state, GDP growth and improving the citizens" welfare. The evaluation criterion here is economic stability.

\section{Issues in Safeguarding Public Interest while Managing Public Finances}

Having analysed the concepts of "public finances", "public interest", "levels of public interest formation", interests of different groups", "functions of public finances" and having established their interconnection, one can suggest that the issues in safeguarding "public interest" while managing "public finances" exist in a few perspectives and, according to the Author, can be classified in the following way.

The first issue is improper fulfilment of the functions of "public finances" (the function of allocation reallocation of resources, stabilization function). This leads to inefficient determination of sources of revenue and expenditure of public budgets; the sources of revenue are reallocated unfairly among the public budgets among the subjects, and neither the stable economic growth, nor the increase of GDP and improvement of citizens' welfare can be ensured. The second issue is the predominance of the interests of one group over another in the process of identifying the "public interest", as well as the formation, reallocation and use of "public finances". The third issue is related to common problems in public administration and public sector (bureaucracy, corruption, lack of trust in public institutes, lack of stability and frequent changes in legislation). The fourth issue is in the area of public authorities and their delegation to the local levels. Local public authority is always more efficient in solving local problems, identifying the scope of "public interests" and forming financial sources for their satisfaction. The question here is how to deal with the problem: to choose the way of decentralization or, on the contrary, centralization in the sphere of "identifying" public interest" and forming and using "public finances". There is a constant scientific discussion on the subject.

To our mind, when dealing with this issue, as well as working out the approach to the solution of the given problems, one should keep in mind one very important thing: all rights come with an equal number or responsibilities for the result and efficiency of the decisions that one makes. K. Engliš put it very clearly: power (i.e. authorities that it has) must be directly determined by the correspondent degree of responsibility. Nobody can be charged with more authority than an entity is ready to take on and be responsible for" (Vencovcký, 1993: 63). 


\section{Conclusions}

Having analysed such concepts as "public finances", "public interest", "levels of public interest development", "interests of different groups "that exist in financial science and having described their nature and goals, as well as their interconnection and the connection with the process of public administration, the Author came to the following conclusion.

The issues in safeguarding "public interest" in the course of managing "public finances" exist in several dimensions and may be classified in the following way. The first issue is about improper fulfilment of the functions of "public finances" (the function of resources allocation and reallocation and the stabilization function). The second issue is about the predominance of interests of one group over another in the course of identifying "public interest", as well as forming, allocating and using "public finances". The third issue is related to common problems that exist in the sphere of public administration and public sector (bureaucracy, corruption, lack of trust in the institutes, lack of stability and frequent changes in legislation). The fourth one is in the field of public authority and their delegation to the local levels and has to do with the necessity to deal with the question of decentralization or, on the contrary, centralization in determining the "public interest" and forming and using "public finances".

\section{References}

Bakeš, M. et al.: Finanční právo (Financial Law), Praha: C.H. Beck, 2006.

Godme, P.M.: Finansovoye pravo (Financial Law), Moscow: C.H. Beck, 1978.

Hamerníková, B., Maaytová, A. et al: Veřejný finance (Public Finance), Praha: Wolters Kluwer, 2010.

Karaseva, M.V.: Pravove regulyuvannya derzhavnikh dokhodiv ta vidatkiv (Some Legal Problems of Government Revenue and Expenditure in the Russian Federation), Kiev: Akad. pravovikh nauk Ukraini, 1998.

Mrkývka, P. et al.: Finanční a daňově právo (Financial and Tax law), Plzeň: Aleš Čeněk, s.r.o., 2009.

Nechay, A.A.: Pravovi problemy rehulyuvannya publichnykh vydatkiv u derzhavi (Legal Issues in the Regulation of Public Expenditure), doctoral dissertation, Kiev: 2005.

Nechay, A.A.: Publichie fondy kak kategoria sovremennogo finansovogo prava (Public Funds as a Category of Modern Financial Law), Zhurnal Rossiyskogo Prava (Journal of Russian Law) no. 11 (2004).

Sheveleva, N.A. et al: Finansovoye pravo (Financial Law), Saint Petersburg: Piter, 2014.

Tikhomirov, Y.A.: Publichnoye pravo (Public Law), Moscow: BEK, 1995.

Vencovský, F.: Karek Engliš (Karel Englis), Brno: Nadace Universitas Masarykiana v Brně, 1993. 